Review

\title{
Crossbreeding of Yeasts Domesticated for Fermentation: Infertility Challenges
}

\author{
Nobuo Fukuda \\ Biomedical Research Institute, National Institute of Advanced Industrial Science and Technology (AIST), \\ 1-8-31 Midorigaoka, Ikeda, Osaka 563-8577, Japan; nob-fukuda@aist.go.jp
}

Received: 24 September 2020; Accepted: 26 October 2020; Published: 27 October 2020

check for updates

\begin{abstract}
Sexual reproduction is almost a universal feature of eukaryotic organisms, which allows the reproduction of new organisms by combining the genetic information from two individuals of different sexes. Based on the mechanism of sexual reproduction, crossbreeding provides an attractive opportunity to improve the traits of animals, plants, and fungi. The budding yeast Saccharomyces cerevisiae has been widely utilized in fermentative production since ancient times. Currently it is still used for many essential biotechnological processes including the production of beer, wine, and biofuels. It is surprising that many yeast strains used in the industry exhibit low rates of sporulation resulting in limited crossbreeding efficiency. Here, I provide an overview of the recent findings about infertility challenges of yeasts domesticated for fermentation along with the progress in crossbreeding technologies. The aim of this review is to create an opportunity for future crossbreeding of yeasts used for fermentation.
\end{abstract}

Keywords: crossbreeding; spore viability; sporulation efficiency; yeasts domesticated for fermentation

\section{Introduction}

Sexual reproduction is ubiquitous in eukaryotes and expands the genetic diversity by producing progeny that resemble their parents but are NOT identical to them [1]. The benefits of sexual reproduction include the purging of deleterious mutations from the genome. Due to genetic recombination and diversification, sexual reproduction can provide a recombinant progeny, well-adapted to a changing environment [2], although there is a twofold cost of sex in relation to asexual reproduction [3-6]. It is rational that numerous species in nature maintain sexual reproduction for survival.

It is known that many species can reproduce both asexually and sexually. Budding yeasts also exhibit asexual and sexual reproductive cycles, whereas the most common mode of vegetative growth is asexual reproduction in both haploid and diploid cells. In haploid cells, there are two cell types determined by the co-dominant a and $\alpha$ alleles, at the MAting Type $(M A T)$ locus $[7,8]$. While haploid cells can be annihilated under high-stress conditions such as nutrient starvation, diploid cells can endure harsh environments by undergoing sporulation during sexual reproduction (meiosis). Through a series of meiotic divisions, the four resulting haploid progenies are packaged into individual spores [9]. Opposite mating type haploid cells mate with each other to reform diploid cells, following spore germination. Similar to that of other fungi, many yeast species preserve sexual reproduction although it is not obligatory [10].

Fermentation of carbohydrate sources into ethanol using yeast species is one of the oldest technologies. The earliest evidence about the existence of a fermented beverage dates to the Neolithic period [11]. As is widely known, various yeast species are still used for many essential biotechnological processes including the production of beer, wine, and biofuels. Saccharomyces cerevisiae is one of the most extensively distinguished yeast species and the preferred host for many bioprocesses 
in large scale fermentations due to its fast growth, well-developed genetics, and fermentation robustness [12]. To increase the productivity and quality, strenuous efforts have been made to generate custom-engineered strains for each fermentation process.

Crossbreeding provides an attractive approach that allows the use of sexual reproduction to generate novel yeast strains exhibiting combined preferred characteristics [13-15]. Similar to that in plants and animals in the agriculture and livestock industry, crossbreeding has been traditionally used for yeast trait modifications in the brewing industry. Unfortunately, however, many industrial strains of $S$. cerevisiae are known to have infertility challenges that manifest as poor sporulation efficiency and spore viability $[8,16]$. In a previous study that tested the capacity of all 318 industrial yeast strains, it was found that $>40 \%$ of the strains did not form spores at all [17]. Despite these infertility challenges, they are preserved as useful organisms with excellent fermentation characteristics in human societies. Here, I review the recent findings about infertility challenges of yeasts domesticated for fermentation, for the future consideration of crossbreeding in the brewing industry. The S. cerevisiae genes described in this review are summarised in Table 1.

Table 1. S. cerevisiae genes described in this review.

\begin{tabular}{|c|c|c|}
\hline Gene & Description & Reference \\
\hline MAT & mating type locus; a or $\alpha$ allele & {$[7,8]$} \\
\hline STE2 & seven transmembrane receptor for $\alpha$-factor pheromone & [18] \\
\hline STE3 & seven transmembrane receptor for a-factor pheromone & [18] \\
\hline MFA1 & mating pheromone a-factor & [18] \\
\hline$M F \alpha 1$ & mating pheromone $\alpha$-factor & [18] \\
\hline GPA1 & GTP-binding $\alpha$ subunit of heterotrimeric G-protein & {$[18,19]$} \\
\hline STE4 & $\beta$ subunit of heterotrimeric G-protein & {$[18,19]$} \\
\hline STE18 & $\gamma$ subunit of heterotrimeric G-protein & {$[18,19]$} \\
\hline IME1 & master regulator of meiosis & {$[20]$} \\
\hline RME1 & zinc finger protein involved in control of meiosis & [20] \\
\hline IRT1 & long noncoding RNA located in the IME1 promoter & {$[21]$} \\
\hline$H M R \mathbf{a} *$ & silenced copy of a sequence & {$[22]$} \\
\hline$H M L \alpha$ & silenced copy of $\alpha$ sequence & {$[22]$} \\
\hline $\mathrm{HO}$ & site-specific endonuclease for the MAT locus & {$[18]$} \\
\hline ASH1 & zinc-finger inhibitor of $\mathrm{HO}$ transcription & [23] \\
\hline SHE1 & type V myosin motor involved in actin-based transport & {$[24]$} \\
\hline SHE2 & RNA-binding protein that binds specific mRNAs & {$[24]$} \\
\hline SHE3 & protein adaptor between She1 and the She2-mRNA complex & {$[24]$} \\
\hline MSN2 & stress responsive transcriptional activator & {$[25,26]$} \\
\hline MSN4 & stress responsive transcriptional activator & {$[25,26]$} \\
\hline RIM15 & protein kinase involved in cell proliferation & [27] \\
\hline$I M E 2$ & serine/threonine protein kinase involved in activation of meiosis & {$[28,29]$} \\
\hline GIS1 & histone demethylase and transcription factor & [30] \\
\hline SPO11 & meiosis-specific protein that initiates meiotic recombination & [31] \\
\hline
\end{tabular}




\section{Sex Determination and Behaviour in Budding Yeasts}

Mating of the opposite mating type haploid cells (MATa and MAT $\alpha$ ) results in the formation of a new diploid strain $(M A T \mathbf{a} / \alpha)$. Phenotypic differences arise from the different gene expression patterns regulated by the MAT loci. The differences in gene expression are summarized in Table 2 . Genes involved in mating are divided into three categories that include a-type-specific genes (asg), $\alpha$-type-specific genes $(\alpha s g)$, and haploid-specific genes $(h s g)$ [32]. MATa haploids express the genes $\boldsymbol{a} 1$ whereas MAT $\alpha$ haploids express the genes $\alpha 1$ and $\alpha 2$. The synthesized protein $\alpha 1$ is the activator of $\alpha \mathrm{sg}$, and $\alpha 2$ functions as a repressor of asg. While the synthesized a1 protein does not influence the expression of mating-related genes, the formation of a1- $\alpha 2$ complex suppresses the expression of $\alpha 1$ and $h s g$ in $M A T \mathbf{a} / \alpha$ diploid cells.

Table 2. Mating type dependent gene expression.

\begin{tabular}{ccccccc}
\hline \multirow{2}{*}{ Cell Type } & \multicolumn{3}{c}{ Mating-Related Genes } & \multicolumn{3}{c}{ Meiosis-Related Genes } \\
\cline { 2 - 7 } & asg & $\alpha s g$ & $h s g$ & RME1 & IRT1 & IME1 \\
\hline $\mathbf{a}^{*}$ & ON & OFF & ON & ON & ON & OFF \\
\hline$\alpha$ & OFF & ON & ON & ON & ON & OFF \\
\hline $\mathbf{a} / \alpha$ & OFF & OFF & OFF & OFF & OFF & ON \\
\hline \multicolumn{4}{c}{${ }^{*}$ The "a"(shown in bold) means mating-type "a". }
\end{tabular}

In $S$. cerevisiae, the process of mating is regulated by a single canonical G-protein signaling pathway [33]. Most of components in this pathway are shared between MATa and MAT $\alpha$ cells (Figure 1). MATa cells express the G-protein coupled receptor (GPCR) Ste2, which detects the $\alpha$-factor mating pheromone expressed from the $M F \alpha 1$ gene in MAT $\alpha$ cells. Reciprocally, MAT $\alpha$ cells express the receptor Ste3, which binds with the a-factor pheromone expressed from the MFA1 gene in MATa cells. Pheromone stimulation leads to the activation of heterotrimeric G-proteins comprising Gpa1 $(\mathrm{G} \alpha)$, Ste4 $(\mathrm{G} \beta)$ and Ste18 $(\mathrm{G} \gamma)$ through the GPCR. The activated G-protein subsequently dissociates into $G \alpha$ and $G \beta \gamma$ complex subunits, and the $G \beta \gamma$ complex induces activation of the mitogen-activated protein kinase (MAPK) cascade [19] followed by transcriptional activation for cell fusion (Figure 1). While the G-protein subunit genes GPA1, STE4, and STE18 are $h s g$, the pheromone and receptor genes are $a s g$ or $\alpha s g$ [18,34]. Expression of these genes is regulated by the MAT gene, resulting in mating behaviors between the MATa and MAT $\alpha$ cells. In the generated MATa $/ \alpha$ diploid cells, pheromone response signal transduction pathway does not function due to the lack of components.

$M A T \mathbf{a} / \alpha$ diploid cells can undergo meiosis under starvation conditions, while MATa and MAT $\alpha$ haploid cells cannot undergo meiosis when exposed to such an environment. Meiosis is regulated by the expression of the Inducer of MEiosis 1 (IME1) gene, commonly known as the master initiator of meiosis [20]. In nutrient-rich environments, IME1 is suppressed by two major nutrient sensing signaling pathways [21,35] (Figure 2). Target of rapamycin complex I (TORC1) and protein kinase A (PKA) activities are suppressed in the absence of nitrogen and glucose. IME1 expression is activated by starvation signaling and repressed by the gene products of the Regulator of MEiosis 1 (RME1) and IME1 Regulatory Transcripts (IRT1) [21]. The difference in gene expression (Table 1) is a result of differential gene regulation by the a1- $\alpha 2$ complex. In both MATa and MAT $\alpha$ haploid cells, the absence of the a1- $\alpha 2$ complex induces expression of the RME1 gene, a member of $h s g$. Rme1 is a zinc finger protein that activates expression of a long noncoding RNA, the product of IRT1, which in turn represses IME1. Meiosis is not induced by starvation signaling in haploid cells, as the expression of the IME1 gene is repressed. In contrast, the a1- $\alpha 2$ complex directly represses the expression of the RME1 gene, and the gene product of IME1 activates the meiosis pathway in $M A T \mathbf{a} / \alpha$ diploid cells in response to starvation. It should be noted that the a1- $\alpha 2$ complex is the most important factor distinguishing $M A T \mathbf{a}$ and $M A T \alpha$ haploids from MATa/ $\alpha$ diploids. 


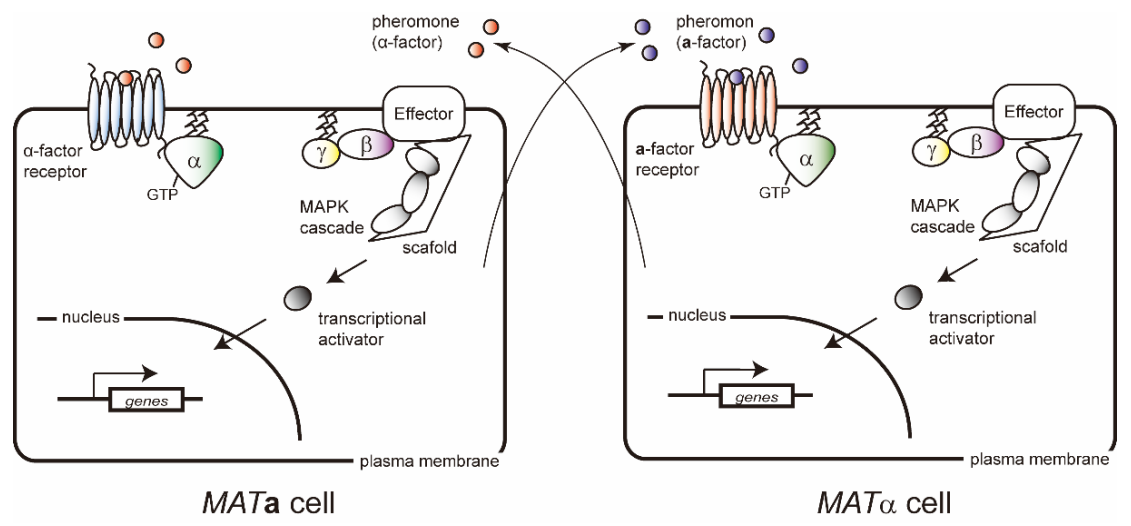

Figure 1. Signal transduction pathway of budding yeasts in response to mating pheromones. Mating pheromones, a-factor and $\alpha$-factor, are secreted from MATa and MAT $\alpha$ cells, respectively. Binding of the mating pheromones to a seven-transmembrane, G-protein-coupled receptor (GPCR) on the cell-surface, leads to activation of heterotrimeric G-proteins composed of $G \alpha, G \beta$, and $G \gamma$. The activated G-proteins subsequently dissociate into G $\alpha$ and a $G \beta \gamma$ dimer, and then $G \beta \gamma$ dimer induces activation of the mitogen-activated protein kinase (MAPK) cascade, resulting in mating-responsive gene expression.

nutrient-rich

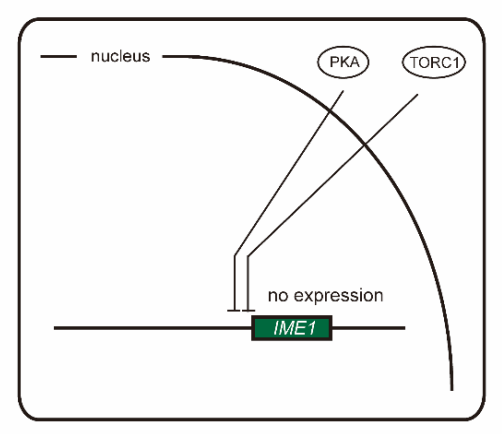

all cell types
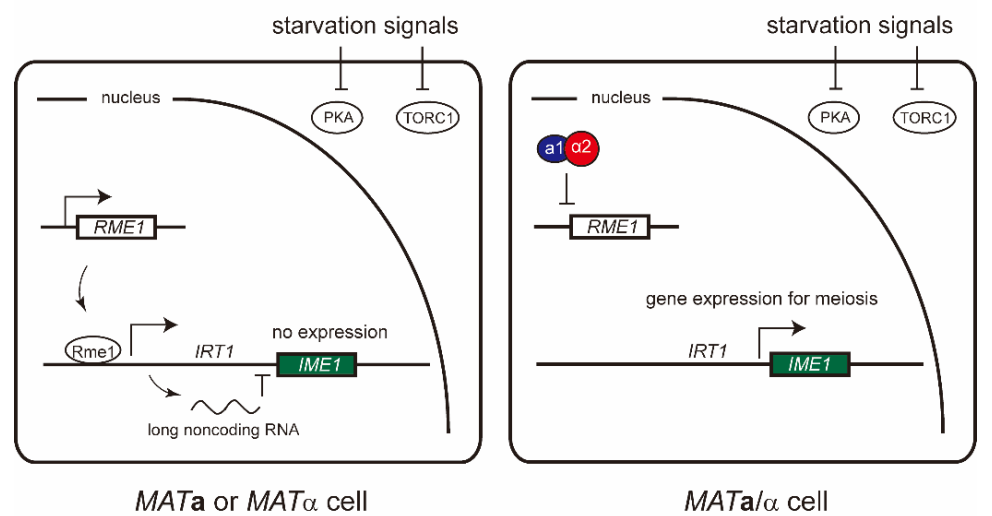

Figure 2. Meiosis is induced by the expression of the Inducer of MEiosis 1 (IME1) gene which is regulated by both mating type and nutrient starvation. In nutrient-rich environments, IME1 is suppressed by the activities of target of rapamycin complex I (TORC1) and protein kinase A (PKA). While IME1 expression is activated by starvation signaling, it is also repressed by the gene products of the Regulator of MEiosis 1 (RME1) and IME1 Regulatory Transcripts (IRT1). In both haploid cells $(M A T \mathbf{a}$ and $M A T \alpha)$, the absence of the a1- $\alpha 2$ complex permits expression of the RME1 gene. Then Rme1 transcribes a long noncoding RNA, the product of IRT1, which in turn represses IME1. The a1- $\alpha 2$ complex directly represses the expression of the RME1 gene, and the gene product of IME1 activates the meiosis pathway in $M A T \mathbf{a} / \alpha$ diploid cells in response to starvation. 


\section{Mating Type Switching and Autodiploidization}

Whereas cell type determination in many multicellular organisms is an irreversible process, the mating types of haploids (a and $\alpha$ ) of the Saccharomycetaceae yeast family can interconvert in a reversible manner by a programmed DNA-rearrangement process called mating type switching $[18,22]$. Following spore germination, many haploid cells mate with the nearby cells of the opposite mating type. In contrast, to mate and become diploid cells, haploid cells that cannot contact the mating partners convert sister cells from one mating type to the other. The endonuclease Ho is responsible for the mating type switching in S. cerevisiae. Following DNA cleavage at the MAT locus, replacement of a or $\alpha$ DNA sequences is induced by the opposite sequences derived from one of the two silent donor loci, HMRa and HML $\alpha$ [36]. It is known that loss-of-function mutations in the HO gene (ho allele) prevent mating type switching of the haploid cells [37]. Yeast strains containing the ho allele are categorized into heterothallic yeasts, whereas homothallic yeasts maintain the $H O$ gene inducing mating type switching in the haploid cells.

The $H O$ gene is a member of $h s g$ and is repressed by the a1- $\alpha 2$ complex in the diploid cells. In addition, mating type switching occurs exclusively in the mother cells, and never in the daughter cells (Figure 3), due to the difference in $\mathrm{HO}$ gene expression. Mother/daughter asymmetric $H O$ gene expression is induced by the product of the HO-specific repressor gene, known as the Asymmetric Synthesis of HO (ASH1) [23]. Delivery of the ASH1 mRNA to the daughter cells is achieved by the products of the Swi5p-dependent HO Expression (SHE) genes. She2 binds to ASH1 mRNA in the nucleus and mediates export to the cytoplasm, after which She3 associates with the ribonucleoprotein particle (RNP). She proteins act as adapters for the type V myosin Myo4 (also called She1), transporting the RNP complex along the actin fiber to the bud tip [24]. ASH1 mRNA is finally translated in the daughter cells, and Ash1 binds its consensus sequences within the upstream repression sequence 1 (URS1) of the HO gene in the following G1 phase. Meanwhile the endonuclease Ho is exclusively synthesized in the mother cells (only during late G1), resulting in mating type switching. Using this programmed DNA-rearrangement, yeasts can proceed with sexual reproduction despite beginning from just a single haploid cell.

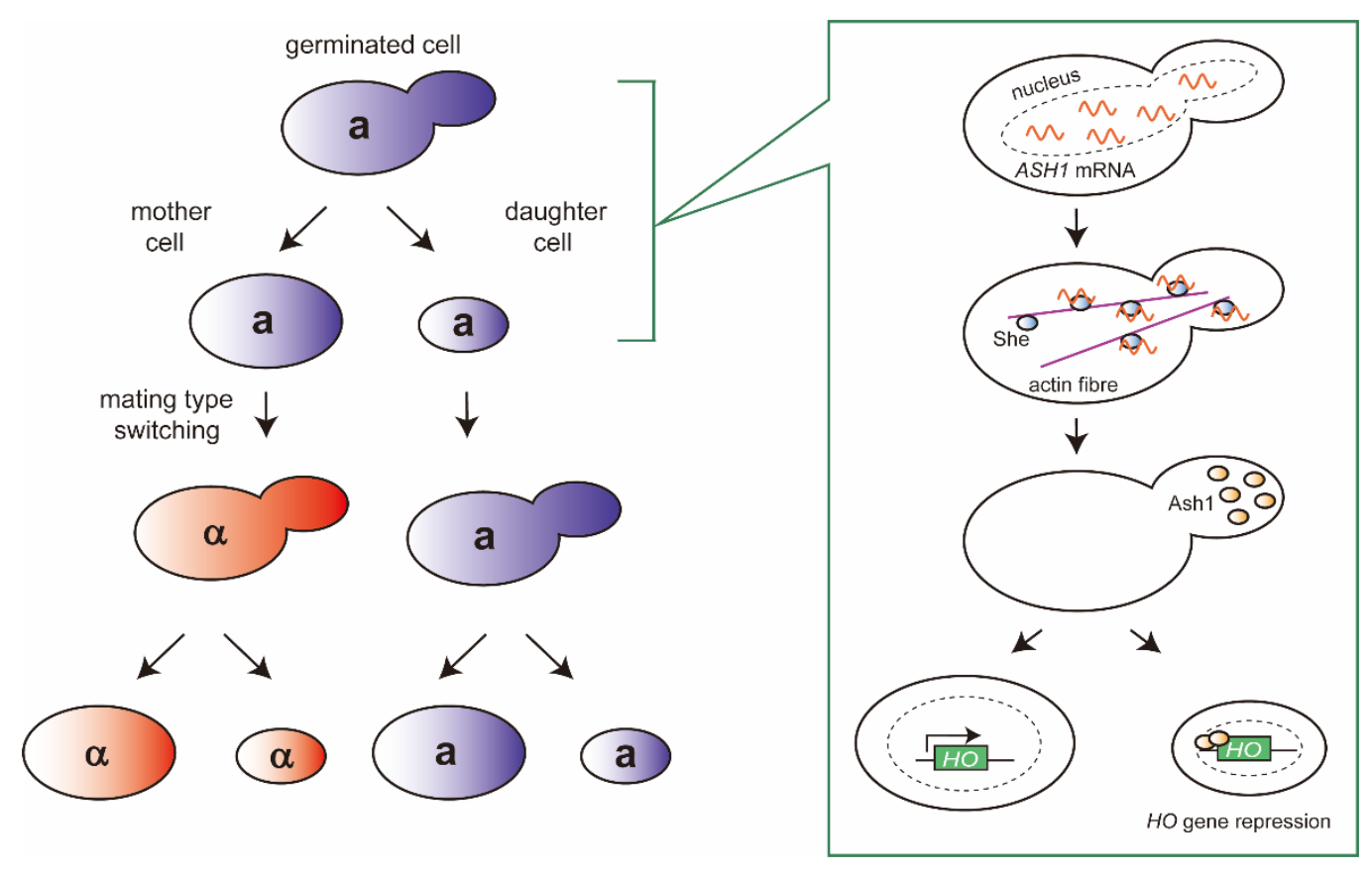

Figure 3. Asymmetric expression of the $H O$ gene between mother and daughter cells. Mating type switching occurs exclusively in the mother cells, and never in the daughter cells. Mother/daughter asymmetric $\mathrm{HO}$ gene expression is induced by the product of the $\mathrm{HO}$-specific repressor gene, Asymmetric 
Synthesis of $H \mathrm{O}$ (ASH1). ASH1 mRNA is delivered to the daughter cells by the products of the Swi5p-dependent HO Expression (SHE) genes. She proteins bind to ASH1 mRNA in the nucleus, mediate export to the cytoplasm, and transport them along the actin fiber to the bud tip. In the daughter cells, Ash1 binds its consensus sequences within the upstream repression sequence 1 (URS1) of the HO gene in the following G1 phase. Meanwhile the endonuclease Ho is exclusively synthesized in the mother cells, resulting in mating type switching.

\section{Infertility Challenges of Industrial Yeasts}

\subsection{Past and Current Situations of Yeast Sporulation}

In 1996, the genome of S. cerevisiae was completely sequenced as the first among the eukaryotic organisms [38]. For several decades, yeast has served as a model for eukaryotic organisms, which has contributed significantly to the progress of cell biology. Compared to the non-essential genes, yeast essential genes exhibited more homologs in the other organisms [39,40]. Importantly, tetrad spore analysis revealed 1105 essential genes of $S$. cerevisiae, based on whether it is possible to acquire haploid cells with the target genes [40,41]. In fact, yeast strains without sporulation deficiency have been utilized for these analyses.

In industrial use, sporulation invites great attention as a means of crossbreeding. Unfortunately, many industrial S. cerevisiae strains are known to exhibit poor ability for sexual reproduction. It was reported that $>80 \%$ of the lager, $>60 \%$ of sake, $>50 \%$ of ale, and $>15 \%$ of wine yeast strains did not undergo sporulation, and more than half of the spores were inviable after dissection in $>80 \%$ of the lager, $>30 \%$ of sake, $>70 \%$ of ale, and $>50 \%$ of wine yeast strains undergoing sporulation [17]. Many species of the Saccharomyces genus other than S. cerevisiae are used for industrial fermentation (including the production of lager beer, wine, and cider), some of which are interspecies hybrids [42-45] such as the lager yeast $S$. pastorianus derived from the two parental species $S$. cerevisiae and S. eubayanus. While these different species can mate, hybrid offspring are almost completely sterile, producing $<1 \%$ viable spores [46]. The hybrid genomes can undergo extensive modifications including loss of chromosomes and various types of recombination events, resulting in aneuploidies, massive copy number variations [47]. Hybrid sterility seems to be mainly caused by the instability of the chromosomes [43].

Regardless of the defects in sexual reproduction, the generated crossbreds (mainly diploid cells) can be continued for use in ethanol fermentation by asexual proliferation. In addition, mutagenesis is also one of the conventional and effective approaches used for modifying certain traits; hence, there is a possibility that numerous industrial yeast strains have been derived from a few strains with defects in sexual reproduction. In modern human societies, industrial yeasts do not need to withstand harsh environmental changes if they maintain excellent characteristics during fermentation. In fact, yeast strains with higher fermentation rates have been historically selected to shorten the fermentation periods and spontaneously inhibit the growth of undesirable microorganisms. Recently, it was found that gene mutations in nutrient-regulated genes are related to high fermentation rates [48].

\subsection{Loss-of-Function Mutations in Nutrient-Regulated Genes}

Sake yeast strains produce significantly more ethanol during fermentation than any other type of S. cerevisiae strains. Gene expression profiling has revealed that the stress-responsive transcription factors Msn2 and Msn4 (Msn2/4) are inactivated in sake yeast strains during fermentation [25,26]. It is known that sake yeast strains are more sensitive to ethanol stress and heat shock than the laboratory strains. Dysfunction of Msn2/4 increases the fermentation rates through the modification of glucose metabolism, including reduced synthesis of storage and structural carbohydrates [48]. Although a specific loss-of-function mutation was found in the MSN4 gene $\left(m s n 4^{C 1540 T}\right)$ of sake yeast strains, this mutation does not appear to be solely responsible for the inactivation of Msn2/4 [43]. In addition, deletion of the MSN4 gene in the S. cerevisiae laboratory strains leads to only a modest increase in their 
fermentation rates [26]. The inactivation of Msn4 is inadequate to achieve the high fermentation rate observed in sake yeasts, suggesting the existence of an alternative factor that inhibits Msn2/4 activities and contributes to the brewing properties.

In S. cerevisiae, nutrient starvation causes inactivation of the nutrient-sensory kinases such as PKA and TORC1, resulting in activation of the PAS kinase Rim15 (Figure 4). RIM15 was identified as one of functionally related genes (Regulator of IME2) that stimulate early meiotic gene expression in yeast [27]. In response to nutrient starvation, RIM15 contributes to gene expression of the IME1 gene [49] and helps IME1 activate the downstream sporulation genes such as IME2 [28,29]. Meanwhile, Rim15-responsive transcripts are involved in stress resistance (essentially heat shock and oxidative stress resistance), carbohydrate metabolism, and respiration [50]. Most of these genes are regulated by the transcription factors, Gis1 binding to the post-diauxic shift (PDS) element, and Msn2/4 recognizing the stress response element (STRE) [30]. Rim15 has been known to be involved in the activation of Msn2/4 (Figure 4) by phosphorylating both N-terminal (1-400) and C-terminal domain (401-704) of Msn2 [51].

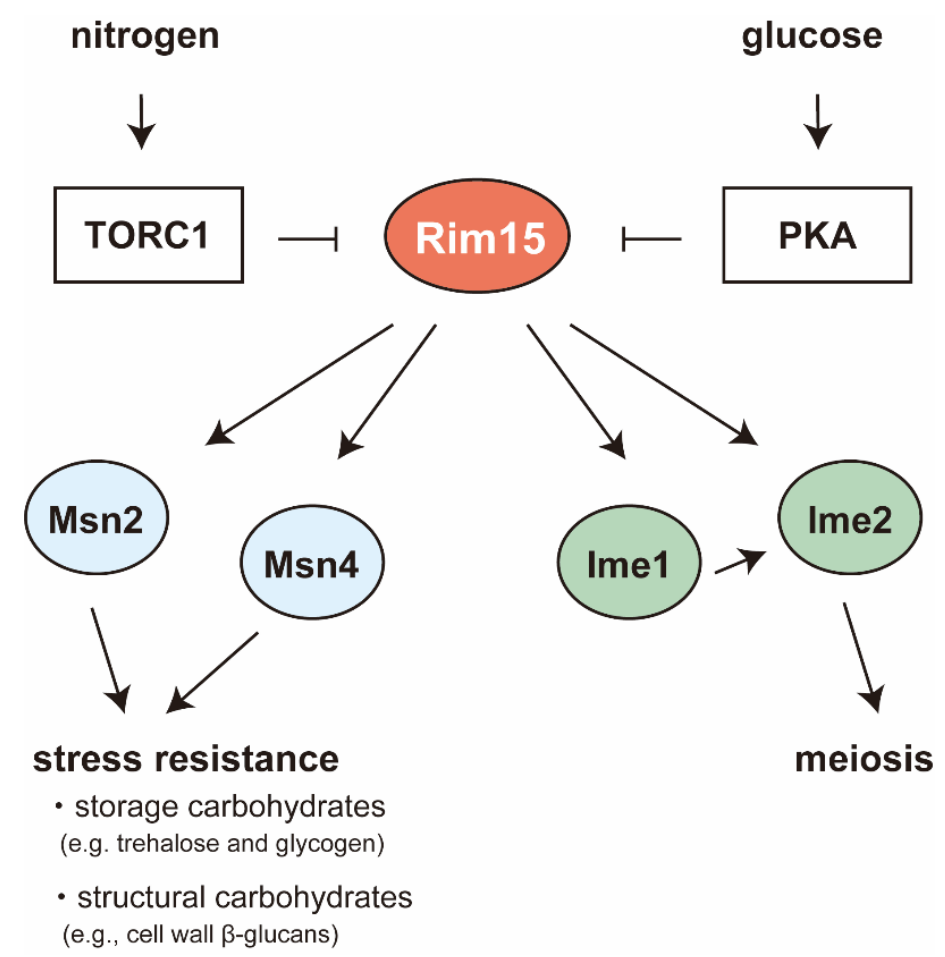

Figure 4. Regulatory cascades around the PAS-kinase Rim15. Rim15-responsive transcripts are involved in stress resistance, carbohydrate metabolism, and respiration. Meanwhile, in response to nutrient starvation, RIM15 contributes to gene expression of the IME1 gene, and helps IME1 activate the downstream sporulation genes such as IME2.

In sake yeast strains, the insertion of a single adenine nucleotide was found immediately after position 5067, compared to that in S. cerevisiae laboratory strains. The frameshift mutation at nucleotide position $5068\left(\right.$ rim1 $15^{5055 i n s}$ ) generates a premature stop codon that shortens the RIM15 gene product by 75 amino acids in the C-terminal region [48], which severely impairs the function of Rim15. Since sake yeast strains contain both copies of the rim15 $5^{5055 i n s} \mathrm{~A}$ mutations, they exhibit a high fermentation rate, stress sensitivity, and severe defects in meiosis. It might be inevitable that infertility challenges are broadly seen in industrial yeasts selected by using fermentation characteristics as the indicator. By introduction of the wild type RIM15 in the sake yeast strains, the sporulation efficiency significantly increased; however, they produced few viable spores [16]. 


\subsection{Chromosome Recombination Defect in Meiosis}

In normal meiosis, the diploid genome is reduced to produce haploid gametes through two rounds of nuclear division that follow a single round of DNA replication (Figure 5). Homologous parental chromosomes pair and separate at the first cell division (meiosis I), while sister chromatids segregate during the second division (meiosis II). One of the main reasons for poor spore viability in industrial yeast strains is a chromosome recombination defect in meiosis. Since meiotic recombination is an essential step for linkage of the homologous parental chromosomes, its absence leads to uneven inheritance of the chromosomes (nondisjunction) leading to aneuploidy and inviable gametes [16]. Spo11 is a meiosis-specific protein that initiates meiotic recombination by catalyzing the transesterification reaction in DNA double-strand breaks. The deletion of the SPO11 gene completely abolishes meiotic recombination, and prevents linkage of the homologous chromosomes, resulting in random segregation of homologous parental chromosomes at meiosis I [31,52].
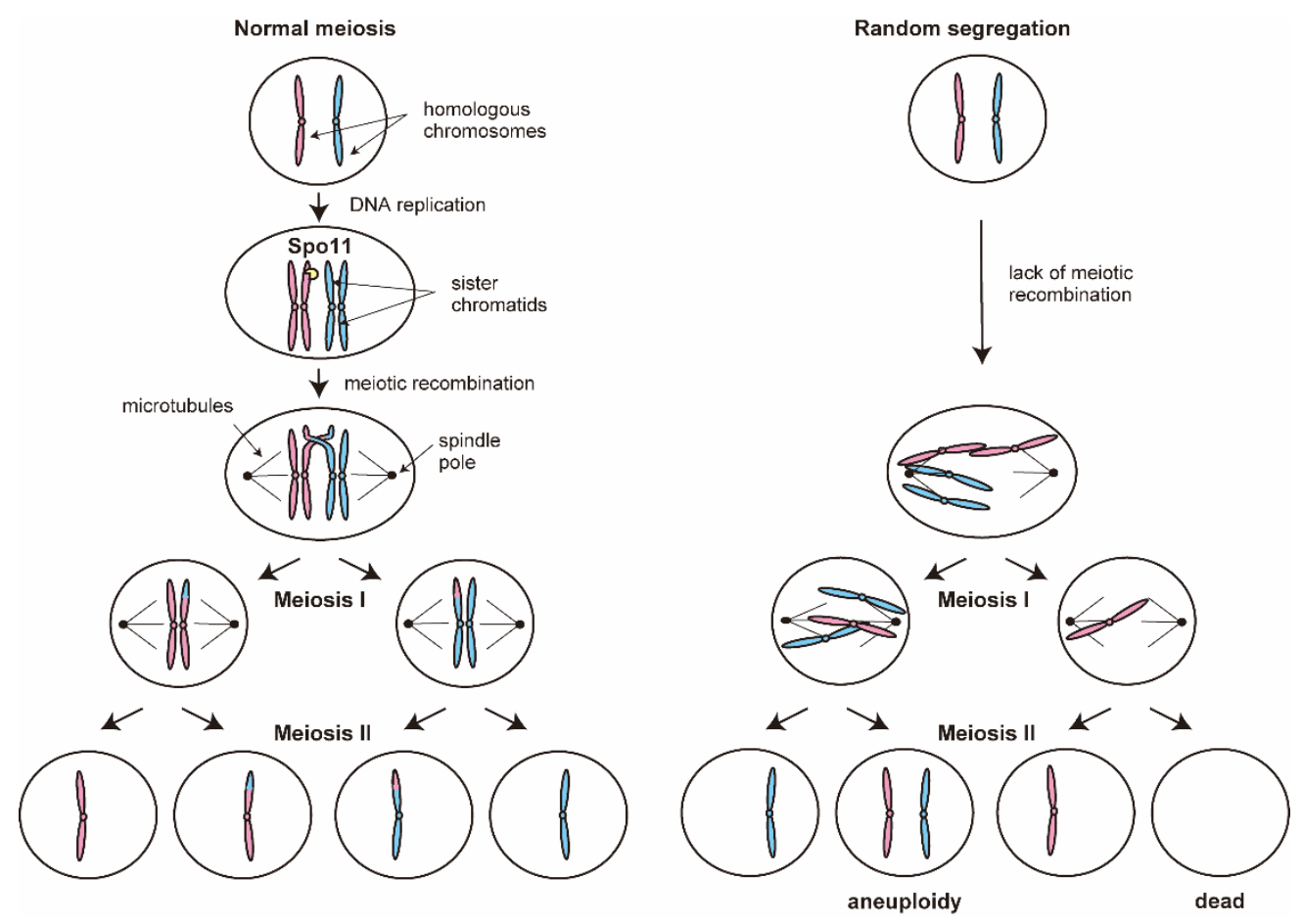

Figure 5. The role of chromosomal recombination in meiosis. Homologous parental chromosomes pair and separate at meiosis I, while sister chromatids segregate during meiosis II. Spo11 is a meiosis-specific protein that initiates meiotic recombination, and the deletion of SPO11 gene completely prevents linkage of the homologous chromosomes, resulting in random segregation of homologous parental chromosomes at meiosis I.

Compared to that in S. cerevisiae laboratory strains, there are several mutations in the SPO11 gene of sake yeast strains. The single nucleotide substitution of C73T (spo11 ${ }^{\mathrm{C} 73 T}$ ) that results in the R25W missense mutation is found in sake yeast strains with significantly poor spore viability. Introduction of spo11 ${ }^{C 73 T}$ to the laboratory strain causes sporulation deficiency and spore non-viability, whereas the transformants with other mutations except for C73T show a high sporulation efficiency and produce many viable colonies [16]. As described above, many sake yeast strains also contain loss-of-function mutations in the nutrient-regulated genes. Therefore, in these strains, introduction of the intact SPO11 cannot completely resolve the infertility challenges. In fact, introduction of both intact RIM15 and SPO11 leads to high sporulation efficiency and spore viability [16]. 


\subsection{Difficulty and Contradiction in Conventional Crossbreeding}

Whole genome and transcriptome analyses have revealed genetic differences between strains of the same species. It was reported that mutations in $>200$ genes affect yeast sporulation $[53,54]$. They have been divided into the following five categories according to gene functions [55-57]: (i) mitochondria/metabolism, (ii) vacuolar and autophagy, (iii) meiosis/early sporulation, (iv) spore formation, and (v) undefined role in sporulation. Mutants in the first two categories arrest the process prior to the meiotic divisions. Sporulation is triggered by nitrogen starvation and requires the presence of a nonfermentable carbon source [58]. The nonfermentable carbon source is metabolized to produce energy via the Krebs cycle and to provide precursors of macromolecules such as nucleic acids, lipids, and polysaccharides required for spore formation. Therefore, respiratory-incompetence blocks entry into sporulation $[59,60]$. Similarly, because new protein synthesis during sporulation requires the recycling of preexisting proteins, many genes involved in delivery of proteins to the vacuole or in autophagy contributes to entry into the meiotic divisions.

In natural selection, these mutations might be purged from the yeast genome. Unfortunately, however, it is not easy to remove the deleterious mutations for sporulation from industrial yeast strains. To begin with, screening methods corresponding to each specific phenotype of interest are usually required for the introduction of a specific change at the target genes. In the case of a phenotype involved in meiosis, observation of individual sporulation consumes immense time to evaluate the clones that have been generated and isolated from the cell population. In addition, some meiosis-related genes such as RIM15 interfere with the fermentation characteristics that need to be improved mainly in the breeding of industrial yeasts. Removal of mutations in these genes inevitably causes a decline in productivity of the fermentation processes without any improvement in the product quality.

Spore viability in interspecific hybrids further declines due to nucleotide divergence [61,62]. The Saccharomyces genus is composed of eight species (S. arboricola, S. cerevisiae, S. eubayanus, S. jurei, S. kudriavzevii, S. mikatae, S. paradoxus and S. uvarum) [63-66], and some studies demonstrated that interspecific hybridization can also occur in nature $[67,68]$. While industrial Saccharomyces hybrids inherit good fermentation performance such as growth ability at lower temperatures [69-73], hybridization gives rise to instability of the chromosomes, which in turn results in spore unviability $[74,75]$. It has been also reported that sporulation efficiency is significantly anticorrelated with the fraction of the genome associated with large $(>20 \mathrm{~kb})$ amplifications and deletions [76]. Aneuploidies and massive copy number variations are also seen in inter-strain hybrids of $S$. cerevisiae. A ploidy study revealed that sake yeast strains (belonging to S. cerevisiae) are mostly diploids, but some are aneuploid [77]. Regarding the effect of chromosomal aneuploidy on the brewing characteristics, it has been reported that trisomy of chromosomes XI and XIV leads to the pyruvate underproduction [78]. Unfortunately, although a variety of yeast strains have been generated using it, the technique of conventional crossbreeding has reached its limit in trait modification of yeast strains with favorable brewing characteristics. To meet the needs of future yeast strain development in industrial use, alternative techniques to bypass sporulation are essentially required to acquire mating-competent yeast cells.

\section{Alternative Techniques for Acquiring Mating-Competent Yeast Cells}

\subsection{Artificial Mating Type Conversion Using the Ho Endonuclease}

The Ho endonuclease expressed in haploid cells of homothallic yeasts has been used for artificial mating type conversion [79]. Through forced expression of the HO gene, replacement of a or $\alpha$ DNA sequences at the MAT loci is induced by opposite mating-type sequences derived from one of two silent donor loci (HMRa and $H M L \alpha)$, also in $M A T \mathbf{a} / \alpha$ diploid cells. By the action of the Ho endonuclease, MATa/a and MAT $\alpha / \alpha$ diploid cells are generated from parental $M A T \mathbf{a} / \alpha$ diploid cells (Figure 6), which possess the same mating ability as either MATa and MAT $\alpha$ haploids generated via sporulation. Since autopolyploidization impedes the isolation of mating-type-converted (MATa/a and 
$M A T \alpha / \alpha)$ cells, hybrid tetraploid strains generated during cocultivation along with the artificial mating type conversion have been selected from the cell population by using marker genes introduced into each parental strain $[80,81]$.

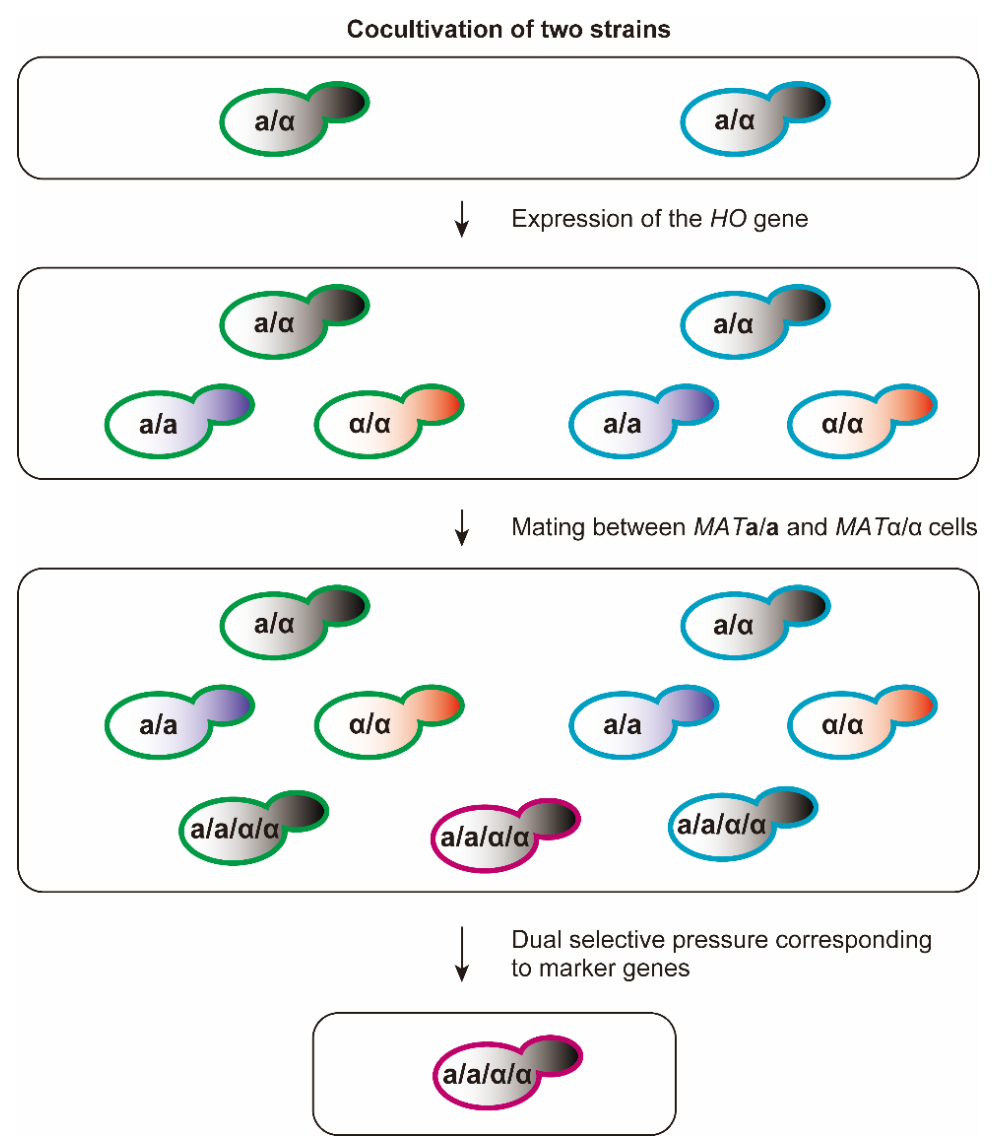

Figure 6. Generation and isolation of hybrid strains using artificial mating type conversion. Different marker genes are introduced into each parental strain. By the action of the Ho endonuclease, $M A T \mathbf{a} / \mathbf{a}$ and $M A T \alpha / \alpha$ diploid cells are generated from parental MATa/ $\alpha$ diploid cells during cocultivation, followed by formation of tetraploid cells. Green and cyan outlines indicate yeast cells possessing different maker genes, whereas purple outline indicates the inheritance of both marker genes. Crossbreeds are screened from cell population under the dual selective pressure corresponding to two marker genes inherited from parent strains.

To avoid autopolyploidization and isolate the mating-competent cells generated through artificial mating type conversion, the a1- $\alpha 2$ complex is artificially formed by introducing synthetic gene expression circuits (Figure 7) into the parental MATa/ $\alpha$ diploid cells, using episomal vectors $[36,82]$. $M A T \mathbf{a} / \mathbf{a}$ or $M A T \alpha / \alpha$ diploids generated through artificial mating type conversion are easily isolated from the cell population since the abundance ratio of target cells in the cell population reaches much beyond $20 \%$ by preventing autopolyploidization [36]. The mating type of the isolated cells can be identified by a mating assay using a and $\alpha$ tester strains [82-84]. Hybrid tetraploid strains are generated through cocultivation of $M A T \mathbf{a} / \mathbf{a}$ and $M A T \alpha / \alpha$ diploids derived from different strains, and selected from the cell population by using marker genes on episomal vectors introduced into each parental strain. By the removal of episomal vectors, the introduced synthetic gene expression circuits can be rendered non-functional in yeast cells, and there is no detection of exogenous DNA throughout the entire genome of crossbreeds [12]. 
For isolation of a type cells

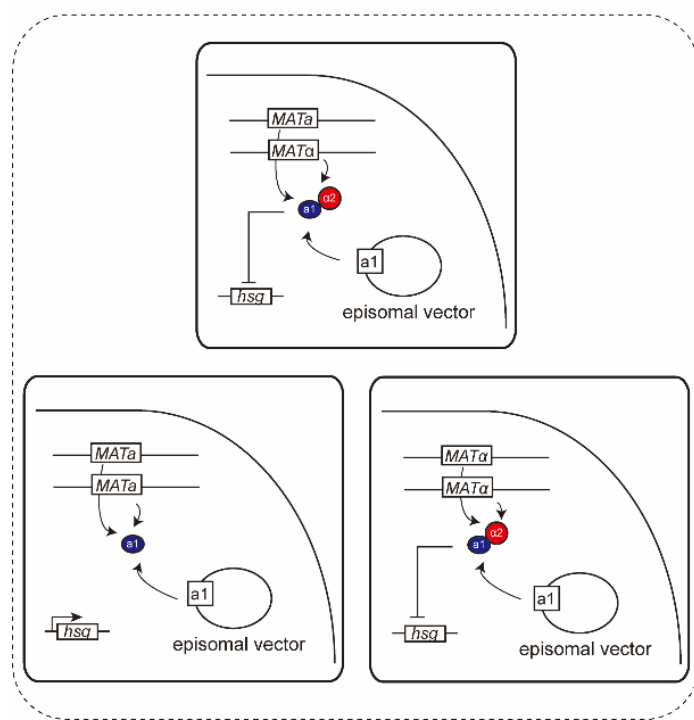

For isolation of a type cells

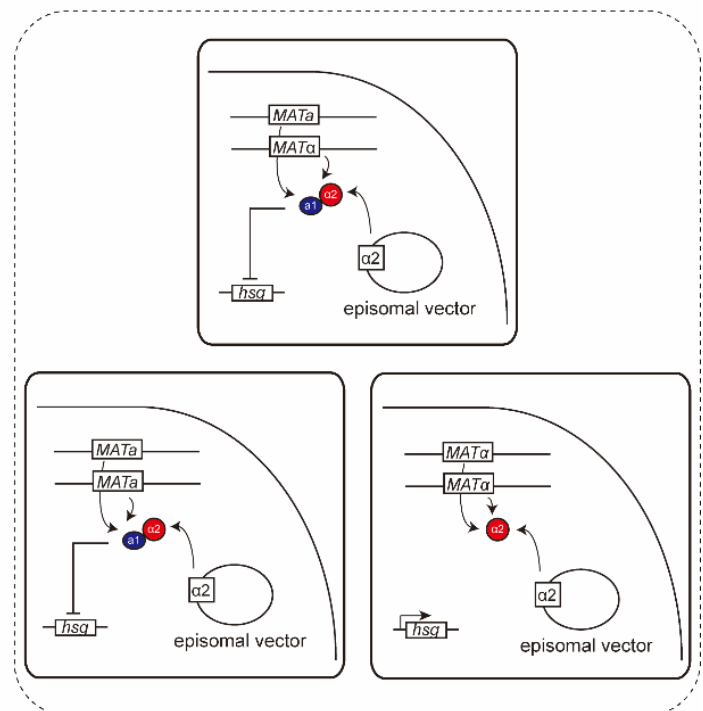

Figure 7. Synthetic gene expression circuit for the a1- $\alpha 2$ complex formation. To prevent autopolyploidation and isolate mating-competent cells generated in artificial mating type conversion, the $\mathbf{a} 1$ or $\alpha 2$ gene is introduced into parental MAT $\mathbf{a} / \alpha$ cells using an episomal vector.

The MAT locus consists of five regions ( $\mathrm{W}, \mathrm{X}, \mathrm{Y}, \mathrm{Z1}$, and $\mathrm{Z} 2)$ based on the sequences shared with the two silent copies, HML $\alpha$ and HMRa [85]. The difference between the a and $\alpha$ type DNA sequences exists in the $\mathrm{Y}$ region ( $\mathrm{Ya}$ or $\mathrm{Y} \alpha$ ). The nucleotide sequences recognized by the Ho endonuclease reside within the $\mathrm{Z1}$ regions of the MAT loci [86]. It is known that a single nucleotide substitution (called stuck mutation) in the $\mathrm{Z} 1$ region prevents mating type switching by severely reducing the Ho endonuclease cleavage. To clarify the presence or absence of stuck mutations, the MAT gene sequences of target strains should be confirmed in advance. Importantly, the mechanism of mating type switching is common among the Saccharomyces genus [22]. There is variation in the sequence of the HO genes between species $[87,88]$, synthetic interspecies hybrids, S. cerevisiae $\times$ S. eubayanus, S. cerevisiae $\times$ S. kudriavzevii, and S. cerevisiae $\times$ S. uvarum, were generated as synthetic lager, Belgian, and cider strains, respectively, by introducing and expressing the $H O$ gene derived from S. cerevisiae [80]. Furthermore, Saccharomyces allopolyploids of six species were similarly generated through mating type conversion of synthetic interspecies hybrids [81], which implies the applicability of these approaches to a wide range of industrial yeast strains (including natural interspecies hybrids).

\subsection{Chromosomal Aberrations Related with Mating Type}

The MAT genes are located on chromosome III, which is the most unstable of all 16 S. cerevisiae chromosomes [89]. This instability irregularly produces other sexual reproduction routes derived from chromosomal aberrations occurring during the mitotic division. There are several kinds of chromosomal aberrations such as loss of heterozygosity $(\mathrm{LOH})$ and mitotic chromosome loss. In diploid cells, $\mathrm{LOH}$ is a naturally occurring process that generates homozygous loci through chromosomal rearrangement of the heterozygous loci [90]. $\mathrm{LOH}$ occurring at the $M A T$ loci within $M A T \mathbf{a} / \alpha$ diploid cells produces either a $M A T \mathbf{a} / \mathbf{a}$ or a $M A T \alpha / \alpha$ diploid cell, whose spontaneous frequency is less than $1 \times 10^{-4}$ [91]. Mitotic chromosome loss is another naturally occurring event where diploid cells lose single or multiple chromosomes [92]. The loss frequency of chromosome III in yeast diploid cells has been reported at $5 \times 10^{-5}$ [89], and yeast cells having lost one of the two copies of chromosome III acquire either a or $\alpha$ type mating ability. While the spontaneous frequencies of such events are quite low, polyploids and aneuploids can be naturally generated not by sporulation but by chromosomal aberration during mitotic division. 
Rare mating based on chromosomal aberration during mitotic division can offer a way to obtain hybrid strains [93]. In a rare mating, MATa/ $\alpha$ diploid cells can hybridize with a haploid cell of the opposite mating type following chromosomal aberration during cocultivation. The isolation of outcrossed hybrids is often achieved by using a respiratory-deficient and an auxotrophic parental strain, making rare hybrids easily selectable by their prototrophy and respiratory proficiency [94-96]. In addition, the isolation of both a and $\alpha$ type mating-competent cells derived from MATa/ $\alpha$ diploid cells is achieved by using the expression of the marker gene in a mating type-specific manner [83,97]. This permits the efficient selection of a or $\alpha$ type cells from within a cell population, despite the significantly low frequency of chromosomal aberration. Meanwhile, dual-dye fluorescent staining was carried out to isolate hybrid cells without using marker genes [98,99]. By labeling each parental strain with a respective fluorescent dye prior to mating, mated cells can be enriched by fluorescence-activated cell sorting (FACS). When applied to rare mating, FACS-based selection of dual-stained cells allowed efficient enrichment of interspecies Saccharomyces hybrids without requiring selectable hybrid phenotypes, both for homothallic and heterothallic strains [99].

\subsection{Conversion of the MAT Gene in Haploid Cells}

Since most of the strains used in industrial use are homothallic [17,100], a haploid in the spore progeny remains only transiently, despite the success in sporulation. In wine yeast strains, conversion of homothallic strains to heterothallism was achieved by introduction of the ho allele [100]. Meanwhile, heterothallic yeasts containing the ho allele are also used in brewing. It is known that most of the modern sake yeast strains are heterothallic yeasts [101]. While facing difficulties in sporulation, many kinds of haploid strains have been generated in the process of crossbreeding. As a matter of course, pairs of the same mating type cannot mate with each other, and conversion of the mating types of either parent is a prerequisite for crossbreeding.

Similar to diploid cells, the Ho endonuclease has been used for the artificial mating type conversion of haploid cells [36,79]. However, it is difficult to convert mating types of yeast strains with stuck mutation at the MAT gene as described above. Recently, the MAT gene of haploid cells was successfully substituted with a synthetic DNA containing MATa or MAT $\alpha$, through homologous recombination [84]. Mating type alteration of yeast cells was performed by suppressing the mating ability of parental cells in the same manner shown in Figure 7. Due to the absence of cell-cell interaction between MATa and MAT $\alpha$ cells, the mating type-altered cells independently exist in the cell population. Regardless of the stuck mutations, all haploid strains of heterothallic yeasts can be utilized for crossbreeding in any combination.

In addition, CRISPR/Cas9 system [102,103] was used for artificial mating type switching through a double-strand break at the MAT locus. According to gRNA sequences, Cas9-mediated double strand breaks (DSBs) are generated at either Ya or Y $\alpha$ region [104]. Unlike mating type conversion using Ho endonuclease, it is possible to switch mating type of yeast strains lacking HMRa and $H M L \alpha$ by addition of the donor DNA segment. Similar to haploid cells, diploid cells were switched to the specified mating type (MATa/a or MAT $\alpha / \alpha)$ using this approach [104]. As described above, mating-competent yeast cells can be acquired without going through sporulation (Figure 8). It might be a potential public concern that some of these methods require genetic modifications, unlike conventional crossbreeding. However, including genome editing with CRISPR/Cas9 system, all genetic modifications can be introduced into the yeast cells using episomal vectors, which allows exclusion of the exogenous DNA throughout the entire genome of crossbreeds after its removal. 


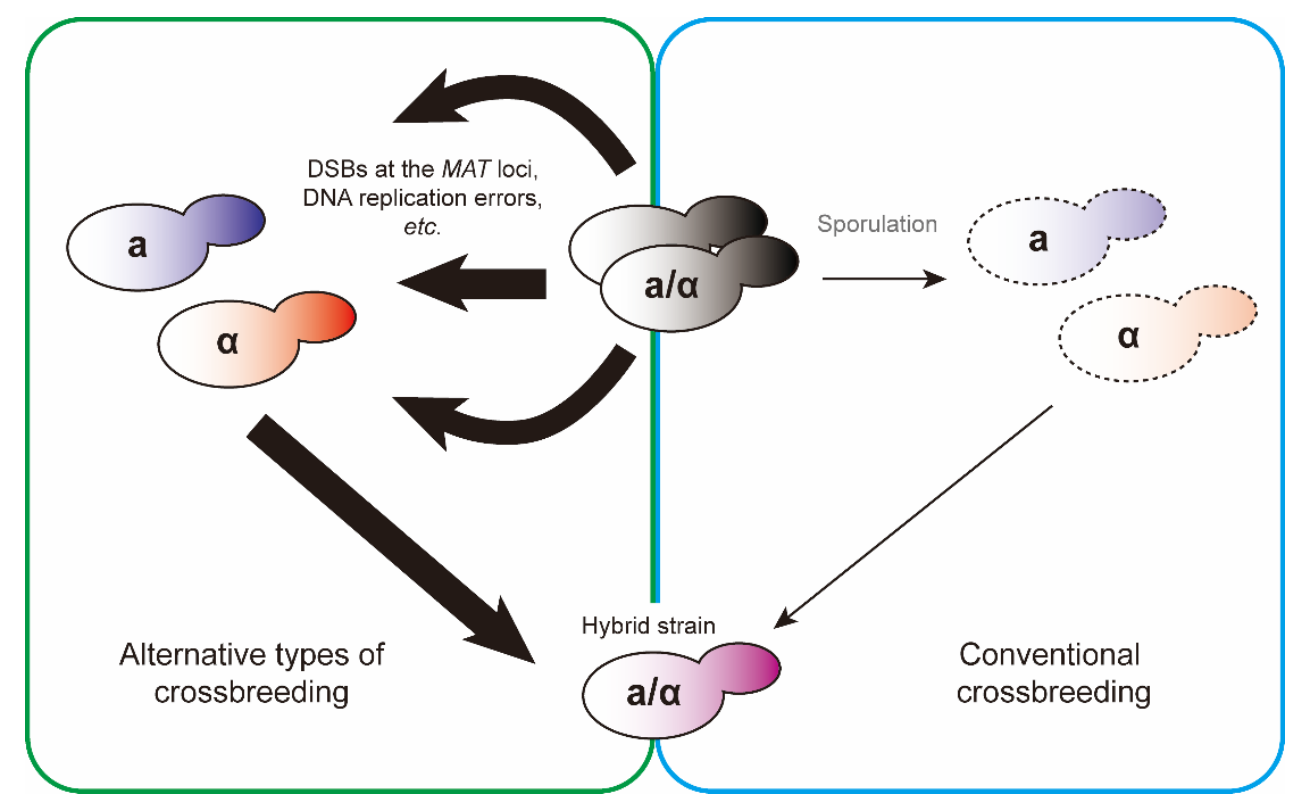

Figure 8. Variations of yeast crossbreeding. Since yeast strains domesticated for fermentation often have infertility challenges, it takes tremendous time and effort to generate hybrid strains in conventional crossbreeding. Meanwhile, mating-competent yeast cells can be acquired through alternative processes such as double strand breaks (DSBs) at the MAT loci and DNA replication errors. The common purpose, which is to generate hybrid strains, would be achieved by using either method.

\section{Conclusions}

Infertility challenges pose a significantly high challenge for yeast trait modification using conventional crossbreeding. There are numerous valuable yeast resources that cannot be fully exploited due to sporulation deficiency. In natural environments, deleterious mutations for sexual reproduction would have been purged from the yeast genome. Industrial yeasts used in modern human societies have acquired excellent characteristics in fermentation with partial sacrifice of sporulation efficiency, due to protection from harsh environmental changes. Although a variety of yeast strains have been generated during the long human history, the technique of conventional crossbreeding used for yeast trait modification based on the molecular mechanism has reached its limit. To meet the needs of future yeast strain development for each custom-engineered fermentation process, alternative techniques to bypass sporulation are essentially required to acquire mating-competent yeast cells. In this review, I have described several alternative methods to generate mating-competent cells from parental yeasts exhibiting severe deficiencies in sporulation. Even if there is a need to use exogenous genes, all genetic modifications described here can be introduced into the yeast cells using episomal vectors, which allows complete removal of the modifications following the isolation of crossbreds. These methods will enable us to improve yeast resources beyond the limitation of conventional crossbreeding by facilitating the generation of new yeast strains exhibiting desirable properties for industrial applications.

Funding: This work was supported by JSPS KAKENHI Grant Number 18K05424.

Conflicts of Interest: The author declares that he is one of inventors on Japanese patent No. 6112548 and 6284139.

\section{Abbreviations}

$\begin{array}{ll}\text { asg } & \text { a-type-specific genes } \\ \alpha s g & \alpha \text {-type-specific genes } \\ \text { DSBs } & \text { double strand breaks } \\ \text { FACS } & \text { fluorescence-activated cell sorting } \\ \text { GPCR } & \text { G-protein coupled receptor }\end{array}$




$\begin{array}{ll}h s g & \text { haploid-specific genes } \\ \text { LOH } & \text { loss of heterozygosity } \\ \text { MAPK } & \text { mitogen activated protein kinase } \\ \text { PDS } & \text { post-diauxic shift } \\ \text { PKA } & \text { protein kinase A } \\ \text { RNP } & \text { ribonucleoprotein particle } \\ \text { STRE } & \text { stress response element } \\ \text { TORC1 } & \text { target of rapamycin complex I } \\ \text { URS } & \text { upstream repression sequence }\end{array}$

\section{References}

1. Xie, Z.X.; Mitchell, L.A.; Liu, H.M.; Li, B.Z.; Liu, D.; Agmon, N.; Wu, Y.; Li, X.; Zhou, X.; Li, B.; et al. Rapid and efficient CRISPR/Cas9-based mating-type switching of Saccharomyces cerevisiae. G3 Genes Genomes Genet. 2018, 8, 173-183. [CrossRef] [PubMed]

2. Fu, C.; Coelho, M.A.; David-Palma, M.; Priest, S.J.; Heitman, J. Genetic and genomic evolution of sexual reproduction: Echoes from LECA to the fungal kingdom. Curr. Opin. Genet. Dev. 2019, 58-59, 70-75. [CrossRef] [PubMed]

3. Suffert, F.; Delestre, G.; Gélisse, S. Sexual Reproduction in the Fungal Foliar Pathogen Zymoseptoria tritici Is Driven by Antagonistic Density Dependence Mechanisms. Microb. Ecol. 2019, 77, 110-123. [CrossRef] [PubMed]

4. Maynard Smith, J. The Evolution of Sex; Cambridge University Press: Cambridge, UK, 1978.

5. Bell, G. The Masterpiece of Nature: The Evolution and Genetics of Sexuality; California University Press: Berkeley, CA, USA, 1982.

6. Roughgarden, J. The evolution of sex. Am. Nat. 1991, 138, 934-953. [CrossRef]

7. Hurst, L.D.; Peck, J.R. Recent advances in understanding of the evolution and maintenance of sex. Trends Ecol. Evol. 1996, 11, 46-52. [CrossRef]

8. Herskowitz, I. Life cycle of the budding yeast Saccharomyces cerevisiae. Microbiol. Rev. 1988, 52, $536-553$. [CrossRef]

9. Nakazawa, N.; Ashikari, T.; Goto, N.; Amachi, T.; Nakajima, R.; Harashima, S.; Oshima, Y. Partial restoration of sporulation defect in sake yeasts, kyokai no. 7 and no. 9, by increased dosage of the IME1 gene. J. Ferment. Bioeng. 1992, 73, 265-270. [CrossRef]

10. Herman, P.K.; Rine, J. Yeast spore germination: A requirement for Ras protein activity during re-entry into the cell cycle. EMBO J. 1997, 16, 6171-6181. [CrossRef]

11. Sun, S.; Heitman, J. Is sex necessary? BMC Biol. 2011, 9, 56. [CrossRef] [PubMed]

12. Duan, S.F.; Han, P.J.; Wang, Q.M.; Liu, W.Q.; Shi, J.Y.; Li, K.; Zhang, X.L.; Bai, F.Y. The origin and adaptive evolution of domesticated populations of yeast from Far East Asia. Nat. Commun. 2018, 9, 2690. [CrossRef] [PubMed]

13. Fukuda, N.; Honda, S. Synthetic gene expression circuits regulating sexual reproduction. Methods Enzymol. 2019, 621, 17-30. [PubMed]

14. Higgins, V.J.; Bell, P.J.L.; Dawes, I.W.; Attfield, P.V. Generation of a novel Saccharomyces cerevisiae strain that exhibits strong maltose utilization and hyperosmotic resistance using nonrecombinant techniques. Appl. Environ. Microbiol. 2001, 67, 4346-4348. [CrossRef] [PubMed]

15. Kishimoto, M. Fermentation characteristics of hybrids between the cryophilic wine yeast Saccharomyces bayanus and the mesophilic wine yeast Saccharomyces cerevisiae. J. Ferment. Bioeng. 1994, 77, 432-435. [CrossRef]

16. Shinohara, T.; Mamiya, S.; Yanagida, F. Introduction of flocculation property into wine yeasts (Saccharomyces cerevisiae) by hybridization. J. Ferment. Bioeng. 1997, 83, 96-101. [CrossRef]

17. Shimoi, H.; Kawamura, N.; Yamada, M. Cloning of the SPO11 gene that complements a meiotic recombination defect in sake yeast. J. Biosci. Bioeng. 2020. Online Ahead of Print. [CrossRef] [PubMed]

18. Sorrells, T.R.; Booth, L.N.; Tuch, B.B.; Johnson, A.D. Intersecting transcription networks constrain gene regulatory evolution. Nature 2015, 523, 361-365. [CrossRef] [PubMed] 
19. Choudhury, S.; Baradaran-Mashinchi, P.; Torres, M.P. Negative feedback phosphorylation of G $\gamma$ subunit Ste18 and the Ste5 scaffold synergistically regulates MAPK activation in yeast. Cell Rep. 2018, 23, 1504-1515. [CrossRef]

20. Hanson, S.J.; Wolfe, K.H. An evolutionary perspective on yeast mating-type switching. Genetics 2017, 206, 9-32. [CrossRef]

21. Weidberg, H.; Moretto, F.; Spedale, G.; Amon, A.; van Werven, F.J. Nutrient control of yeast gametogenesis is mediated by TORC1, PKA and energy availability. PLoS Genet. 2016, 12, e1006075. [CrossRef]

22. Moretto, F.; van Werven, F.J. Transcription of the mating-type-regulated lncRNA IRT1 is governed by TORC1 and PKA. Curr. Genet. 2017, 63, 325-329. [CrossRef]

23. van Zyl, W.H.; Lodolo, E.J.; Gericke, M. Conversion of homothallic yeast to heterothallism through HO gene disruption. Curr. Genet. 1993, 23, 290-294. [CrossRef] [PubMed]

24. Cosma, M.P. Daughter-specific repression of Saccharomyces cerevisiae HO: Ash1 is the commander. EMBO rep. 2004, 5, 953-957. [CrossRef] [PubMed]

25. Watanabe, D.; Araki, Y.; Zhou, Y.; Maeya, N.; Akao, T.; Shimoia, H. A Loss-of-function mutation in the PAS kinase Rim15p is related to defective quiescence entry and high fermentation rates of Saccharomyces cerevisiae sake yeast strains. Appl. Environ. Microbiol. 2012, 78, 4008-4016. [CrossRef] [PubMed]

26. Noguchi, C.; Watanabe, D.; Zhou, Y.; Akao, T.; Shimoi, H. Association of constitutive hyperphosphorylation of Hsf1p with a defective ethanol stress response in Saccharomyces cerevisiae sake yeast strains. Appl. Environ. Microbiol. 2012, 78, 385-392. [CrossRef] [PubMed]

27. Watanabe, D.; Wu, H.; Noguchi, C.; Zhou, Y.; Akao, T.; Shimoi, H. Enhancement of the initial rate of ethanol fermentation due to dysfunction of yeast stress response components Msn2p and/or Msn4p. Appl. Environ. Microbiol. 2011, 77, 934-941. [CrossRef]

28. Vidan, S.; Mitchell, A.P. Stimulation of yeast meiotic gene expression by the glucose-repressible protein kinase Rim15p. Mol. Cell. Biol. 1997, 17, 2688-2697. [CrossRef]

29. Smith, H.E.; Mitchell, A.P. A transcriptional cascade governs entry into meiosis in Saccharomyces cerevisiae. Mol. Cell. Biol. 1989, 9, 2142-2152. [CrossRef]

30. Cameroni, E.; Hulo, N.; Roosen, J.; Winderickx, J.; De Virgilio, C. The novel yeast PAS kinase Rim 15 orchestrates G0-associated antioxidant defense mechanisms. Cell Cycle 2004, 3, 462-468. [CrossRef]

31. Lee, P.; Kim, M.S.; Paik, S.M.; Choi, S.H.; Cho, B.R.; Hahn, J.S. Rim15-dependent activation of Hsf1 and Msn2/4 transcription factors by direct phosphorylation in Saccharomyces cerevisiae. FEBS Lett. 2013, 587, 3648-3655. [CrossRef]

32. Snoek, T.; Nicolino, M.P.; Van den Bremt, S.; Mertens, S.; Saels, V.; Verplaetse, A.; Steensels, J.; Verstrepen, K.J. Large-scale robot-assisted genome shuffling yields industrial Saccharomyces cerevisiae yeasts with increased ethanol tolerance. Biotechnol. Biofuels 2015, 8, 32. [CrossRef]

33. Haber, J.E. Mating-type gene switching in Saccharomyces cerevisiae. Annu. Rev. Genet. 1998, 32, 561-599. [CrossRef] [PubMed]

34. Fukuda, N.; Ishii, J.; Tanaka, T.; Fukuda, H.; Kondo, A. Construction of a novel detection system for protein-protein interactions using yeast G-protein signaling. FEBS J. 2009, 276, 2636-2644. [CrossRef] [PubMed]

35. Gelfand, B.; Mead, J.; Bruning, A.; Apostolopoulos, N.; Tadigotla, V.; Nagaraj, V.; Sengupta, A.M.; Vershon, A.K. Regulated antisense transcription controls expression of cell-type-specific genes in yeast. Mol. Cell. Biol. 2011, 31, 1701-1709. [CrossRef] [PubMed]

36. Hanson, S.J.; Byrne, K.P.; Wolfe, K.H. Mating-type switching by chromosomal inversion in methylotrophic yeasts suggests an origin for the three-locus Saccharomyces cerevisiae system. Proc. Natl. Acad. Sci. USA 2014, 111, E4851-E4858. [CrossRef]

37. Fukuda, N.; Matsukura, S.; Honda, S. Artificial conversion of the mating-type of Saccharomyces cerevisiae without autopolyploidization. ACS Synth. Biol. 2013, 2, 697-704. [CrossRef]

38. Jansen, R.P.; Dowzer, C.; Michaelis, C.; Galova, M.K.; Nasmyth, K. Mother cell-specific HO expression in budding yeast depends on the unconventional myosin myo4p and other cytoplasmic proteins. Cell 1996, 84, 687-697. [CrossRef]

39. Goffeau, A.; Barrell, B.G.; Bussey, H.; Davis, R.W.; Dujon, B.; Feldmann, H.; Galibert, F.; Hoheisel, J.D.; Jacq, C.; Johnston, M.; et al. Life with 6000 genes. Science 1996, 274, 563-567. [CrossRef] 
40. Winzeler, E.A.; Shoemaker, D.D.; Astromoff, A.; Liang, H.; Anderson, K.; Andre, B.; Bangham, R.; Benito, R.; Boeke, J.D.; Bussey, H.; et al. Functional characterization of the S. cerevisiae genome by gene deletion and parallel analysis. Science 1999, 285, 901-906. [CrossRef]

41. Giaever, G.; Chu, A.M.; Ni, L.; Connelly, C.; Riles, L.; Véronneau, S.; Dow, S.; Lucau-Danila, A.; Anderson, K.; André, B.; et al. Functional profiling of the Saccharomyces cerevisiae genome. Nature 2002, 418, 387-391. [CrossRef]

42. Liu, G.; Yong, M.Y.J.; Yurieva, M.; Srinivasan, K.G.; Liu, J.; Lim, J.S.Y.; Poidinger, M.; Wright, G.D.; Zolezzi, F.; Choi, H.; et al. Gene essentiality is a quantitative property linked to cellular evolvability. Cell 2015, 163, 1388-1399. [CrossRef]

43. Monerawela, C.; Bond, U. Brewing up a storm: The genomes of lager yeasts and how they evolved. Biotechnol. Adv. 2017, 35, 512-519. [CrossRef] [PubMed]

44. Carro, D.; Piña, B. Genetic analysis of the karyotype instability in natural wine yeast strains. Yeast 2001, 18, 1457-1470. [CrossRef] [PubMed]

45. Masneuf, I.; Hansen, J.; Groth, C.; Piskur, J.; Dubourdieu, D. New hybrids between Saccharomyces sensu stricto yeast species found among wine and cider production strains. Appl. Environ. Microbiol. 1998, 64, 3887-3892. [CrossRef] [PubMed]

46. Sipiczki, M. Interspecies hybridization and recombination in Saccharomyces wine yeasts. FEMS Yeast Res. 2008, 8, 996-1007. [CrossRef]

47. Greig, D.; Borts, R.H.; Louis, E.J.; Travisano, M. Epistasis and hybrid sterility in Saccharomyces. Proc. R. Soc. Lond. B 2002, 269, 1167-1171. [CrossRef]

48. Steenwyk, J.L.; Rokas, A. Copy Number Variation in Fungi and Its Implications for Wine Yeast Genetic Diversity and Adaptation. Front. Microbiol. 2018, 9, 288. [CrossRef]

49. Su, S.S.; Mitchell, A.P. Identification of functionally related genes that stimulate early meiotic gene expression in yeast. Genetics 1993, 133, 67-77.

50. Lorenz, K.; Cohen, B.A. Causal Variation in Yeast Sporulation Tends to Reside in a Pathway Bottleneck. PLoS Genet. 2014, 10, e1004634. [CrossRef]

51. Bisschops, M.M.M.; Zwartjens, P.; Keuter, S.G.F.; Pronk, J.T.; Daran-Lapujade, P. To divide or not to divide: A key role of Rim15 in calorie-restricted yeast cultures. Biochim. Biophys. Acta 2014, 1843, 1020-1030. [CrossRef]

52. Keeney, S.; Giroux, C.N.; Kleckner, N. Meiosis-specific DNA double-strand breaks are catalyzed by Spo11, a member of a widely conserved protein family. Cell 1997, 88, 375-384. [CrossRef]

53. Hunter, N. Meiotic Recombination: The Essence of Heredity. Cold Spring Harb. Perspect. Biol. 2015, 7, a016618. [CrossRef] [PubMed]

54. Neiman, A.M. Ascospore formation in the yeast Saccharomyces cerevisiae. Microbiol. Mol. Biol. Rev. 2005, 69, 565-584. [CrossRef] [PubMed]

55. Shimoi, H.; Hanazumi, Y.; Kawamura, N.; Yamada, M.; Shimizu, S.; Suzuki, T.; Daisuke Watanabe, D.; Akao, T. Meiotic chromosomal recombination defect in sake yeasts. J. Biosci. Bioeng. 2019, 127, 190-196. [CrossRef] [PubMed]

56. Enyenihi, A.H.; Saunders, W.S. Large-scale functional genomic analysis of sporulation and meiosis in Saccharomyces cerevisiae. Genetics 2003, 163, 47-54.

57. Chu, S.; DeRisi, J.; Eisen, M.; Mulholland, J.; Botstein, D.; Brown, P.O.; Herskowitz, I. The transcriptional program of sporulation in budding yeast. Science 1998, 282, 699-705. [CrossRef]

58. Primig, M.; Williams, R.M.; Winzeler, E.A.; Tevzadze, G.G.; Conway, A.R.; Hwang, S.Y.; Davis, R.W.; Esposito, R.E. The core meiotic transcriptome in budding yeasts. Nat. Genet. 2000, 26, 415-423. [CrossRef]

59. Nickas, M.E.; Diamond, A.E.; Yang, M.J.; Neiman, A.M. Regulation of spindle pole function by an intermediary metabolite. Mol. Biol. Cell 2004, 15, 2606-2616. [CrossRef]

60. Newlon, M.C.; Hall, B.D. Inhibition of yeast sporulation by ethidium bromide. Mol. Gen. Genet. 1978, 165, 113-114. [CrossRef]

61. Tsuboi, M.; Kondo, K.; Yanagishima, N. Inhibition of sporulation by ethidium bromide and its reversal by fermentable sugars in Saccharomyces cerevisiae. Arch Microbiol. 1974, 99, 295-305. [CrossRef]

62. Greig, D. Reproductive isolation in Saccharomyces. Heredity 2009, 102, 39-44. [CrossRef]

63. Liti, G.; Barton, D.B.H.; Louis, E.J. Sequence diversity, reproductive isolation and species concepts in Saccharomyces. Genetics 2006, 174, 839-850. [CrossRef] [PubMed] 
64. Boynton, P.J.; Greig, D. The ecology and evolution of non-domesticated Saccharomyces species. Yeast 2014, 31, 449-462.

65. Naseeb, S.; James, S.A.; Alsammar, H.; Michaels, C.J.; Gini, B.; Nueno-Palop, C.; Bond, C.J.; McGhie, H.; Roberts, I.N.; Delneri, D. Saccharomyces jurei sp. nov., isolation and genetic identification of a novel yeast species from Quercus robur. Int. J. Syst. Evol. Microbiol. 2017, 67, 2046-2052. [PubMed]

66. Hittinger, C.T. Saccharomyces diversity and evolution: A budding model genus. Trends Genet. 2013, 29, 309-317. [CrossRef] [PubMed]

67. Morard, M.; Benavent-Gil, Y.; Ortiz-Tovar, G.; Pérez-Través, L.; Querol, A.; Toft, C.; Barrio, E. Genome structure reveals the diversity of mating mechanisms in Saccharomyces cerevisiae $\mathrm{x}$ Saccharomyces kudriavzevii hybrids, and the genomic instability that promotes phenotypic diversity. Microb. Genom. 2020, 6, e000333. [CrossRef] [PubMed]

68. Stefanini, I.; Dapporto, L.; Berná, L.; Polsinelli, M.; Turillazzi, S.; Cavalieri, D. Social wasps are a Saccharomyces mating nest. Proc. Natl. Acad. Sci. USA 2016, 113, 2247-2251. [CrossRef] [PubMed]

69. Pulvirenti, A.; Zambonelli, C.; Todaro, A.; Giudici, P. Interspecific hybridisation by digestive tract of invertebrates as a source of environmental biodiversity within the Saccharomyces cerevisiae. Ann. Microbiol. 2002, 52, 245-255.

70. Krogerus, K.; Preiss, R.; Gibson, B. A unique Saccharomyces cerevisiae $\times$ Saccharomyces uvarum hybrid isolated from Norwegian Farmhouse beer: Characterization and reconstruction. Front. Microbiol. 2018, 9, 2253. [CrossRef]

71. Gibson, B.R.; Storgårds, E.; Krogerus, K.; Vidgren, V. Comparative physiology and fermentation performance of Saaz and Frohberg lager yeast strains and the parental species Saccharomyces eubayanus. Yeast 2013, 30, 255-266. [CrossRef]

72. Ortiz-Tovar, G.; Pérez-Torrado, R.; Adam, A.C.; Barrio, E.; Querol, A. A comparison of the performance of natural hybrids Saccharomyces cerevisiae $\times$ Saccharomyces kudriavzevii at low temperatures reveals the crucial role of their S. kudriavzevii genomic contribution. Int. J. Food Microbiol. 2018, 274, 12-19. [CrossRef]

73. Belloch, C.; Orlic, S.; Barrio, E.; Querol, A. Fermentative stress adaptation of hybrids within the Saccharomyces sensu stricto complex. Int. J. Food Microbiol. 2008, 122, 188-195. [CrossRef]

74. Pérez-Torrado, R.; González, S.S.; Combina, M.; Barrio, E.; Querol, A. Molecular and enological characterization of a natural Saccharomyces uvarum and Saccharomyces cerevisiae hybrid. Int. J. Food Microbiol. 2015, 204, 101-110. [CrossRef] [PubMed]

75. Sipiczki, M. Interspecies hybridisation and genome chimerisation in Saccharomyces combining of gene pools of species and its biotechnological perspectives. Front. Microbiol. 2018, 9, 3071. [CrossRef] [PubMed]

76. Guillamón, J.M.; Barrio, E. Genetic polymorphism in wine yeasts: Mechanisms and methods for its detection. Front. Microbiol. 2017, 8, 806. [CrossRef] [PubMed]

77. Gallone, B.; Steensels, J.; Prahl, T.; Soriaga, L.; Saels, V.; Herrera-Malaver, B.; Merlevede, A.; Roncoroni, M.; Voordeckers, K.; Miraglia, L.; et al. Domestication and divergence of Saccharomyces cerevisiae beer yeasts. Cell 2016, 166, 1397-1410.e16. [CrossRef]

78. Ohya, Y.; Kashima, M. History, lineage and phenotypic differentiation of sake yeast. Biosci. Biotechnol. Biochem. 2019, 83, 1442-1448. [CrossRef]

79. Kadowaki, M.; Fujimaru, Y.; Taguchi, S.; Ferdouse, J.; Sawada, K.; Kimura, Y.; Terasawa, Y.; Agrimi, G.; Anai, T.; Noguchi, H.; et al. Chromosomal aneuploidy improves the brewing characteristics of sake yeast. Appl. Environ. Microbiol. 2017, 83, e01620-e17. [CrossRef]

80. Herskowitz, I.; Jensen, R.E. Putting the $H O$ gene to work: Practical uses for mating type switching. Methods Enzymol. 1991, 194, 132-146.

81. Alexander, W.G.; Peris, D.; Pfannenstiel, B.T.; Opulente, D.A.; Kuang, M.; Hittinger, C.T. Efficient engineering of marker-free synthetic allotetraploids of Saccharomyces. Fungal Genet. Biol. 2016, 89, 10-17. [CrossRef]

82. Peris, D.; Alexander, W.G.; Fisher, K.J.; Moriarty, R.V.; Basuino, M.G.; Ubbelohde, E.J.; Wrobel, R.L.; Hittinger, C.T. Synthetic hybrids of six yeast species. Nat. Commun. 2020, 11, 2085. [CrossRef]

83. Fukuda, N.; Honda, S. Artificial mating-type conversion and repetitive mating for polyploid generation. ACS Synth. Biol. 2018, 7, 1413-1423. [CrossRef] [PubMed]

84. Fukuda, N.; Kaishima, M.; Ishii, J.; Kondo, A.; Honda, S. Continuous crossbreeding of sake yeasts using growth selection systems for a-type and $\alpha$-type cells. AMB Express. 2016, 6, 45. [CrossRef] 
85. Fukuda, N. A new scheme to artificially alter yeast mating-types without autodiploidization. Fungal Genet. Biol. 2020. Online Ahead of Print. [CrossRef]

86. Haber, J.E. Mating-type genes and MAT switching in Saccharomyces cerevisiae. Genetics 2012, 191, 33-64. [CrossRef] [PubMed]

87. Ray, B.L.; White, C.I.; Haber, J.E. Heteroduplex formation and mismatch repair of the "stuck" mutation during mating-type switching in Saccharomyces cerevisiae. Mol. Cell. Biol. 1991, 11, 5372-5380. [CrossRef] [PubMed]

88. Tamai, Y.; Tanaka, K.; Umemoto, N.; Tomizuka, K.; Kaneko, Y. Diversity of the HO gene encoding an endonuclease for mating-type conversion in the bottom fermenting yeast Saccharomyces pastorianus. Yeast 2000, 16, 1335-1343. [CrossRef]

89. Tamai, Y.; Kanai, K.; Kaneko, Y. A structural and phylogenetic study of the HO gene from Saccharomyces bayanus var. uvarum. Biosci. Biotechnol. Biochem. 2007, 71, 1850-1857. [CrossRef] [PubMed]

90. Kumaran, R.; Yang, S.Y.; Leu, J.Y. Characterization of chromosome stability in diploid, polyploid and hybrid yeast cells. PLoS ONE 2013, 8, e68094. [CrossRef]

91. Andersen, M.P.; Nelson, Z.W.; Hetrick, E.D.; Gottschling, D.E. A genetic screen for increased loss of heterozygosity in Saccharomyces cerevisiae. Genetics 2008, 179, 1179-1195. [CrossRef]

92. Hiraoka, M.; Watanabe, K.; Umezu, K.; Maki, H. Spontaneous loss of heterozygosity in diploid Saccharomyces cerevisiae cells. Genetics 2000, 156, 1531-1548.

93. Mayer, V.W.; Aguilera, A. High levels of chromosome instability in polyploids of Saccharomyces cerevisiae. Mutat. Res. 1990, 231, 177-186. [CrossRef]

94. Gunge, N.; Nakatomi, Y. Genetic mechanisms of rare matings of the yeast Saccharomyces cerevisiae heterozygous for mating type. Genetics 1972, 70, 41-58.

95. Pretorius, I.S. Tailoring wine yeast for the new millennium: Novel approaches to the ancient art of winemaking. Yeast 2000, 16, 675-729. [CrossRef]

96. Hammond, J.R.M. Yeast Genetics. Brew. Microbiol. 2003, 3, 67-112.

97. Steensels, J.; Snoek, T.; Meersman, E.; Nicolino, M.P.; Voordeckers, K.; Verstrepen, K.J. Improving industrial yeast strains: Exploiting natural and artificial diversity. FEMS Microbiol. Rev. 2014, 38, 947-995. [CrossRef] [PubMed]

98. Fukuda, N.; Honda, S. Development of growth selection systems to isolate a-type or $\alpha$-type of yeast cells spontaneously emerging from MATa/ $\alpha$ diploids. J. Biol. Eng. 2013, 7, 27. [CrossRef] [PubMed]

99. Bell, P.J.; Deere, D.; Shen, J.; Chapman, B.; Bissinger, P.H.; Attfield, P.V.; Veal, D.A. A flow cytometric method for rapid selection of novel industrial yeast hybrids. Appl. Environ. Microbiol. 1998, 64, 1669-1672. [CrossRef]

100. Gorter de Vries, A.R.; Koster, C.C.; Weening, S.M.; Luttik, M.A.H.; Kuijpers, N.G.A.; Geertman, J.M.A.; Pronk, J.T.; Daran, J.M.G. Phenotype-independent isolation of interspecies Saccharomyces hybrids by dual-dye fluorescent staining and fluorescence-activated cell sorting. Front. Microbiol. 2019, 10, 871. [CrossRef] [PubMed]

101. Bakalinsky, A.T.; Snow, R. Conversion of Wine Strains of Saccharomyces cerevisiae to Heterothallism. Appl. Environ. Microbiol. 1990, 56, 849-857. [CrossRef] [PubMed]

102. Katou, T.; Kitagaki, H.; Akao, T.; Shimoi, H. Brewing characteristics of haploid strains isolated from sake yeast Kyokai No. 7. Yeast 2008, 25, 799-807. [CrossRef] [PubMed]

103. Jinek, M.; Chylinski, K.; Fonfara, I.; Hauer, M.; Doudna, J.A.; Charpentier, E. A programmable dual-RNA-guided DNA endonuclease in adaptive bacterial immunity. Science 2012, 337, 816-821. [CrossRef]

104. Cong, L.; Ran, F.A.; Cox, D.; Lin, S.; Barretto, R.; Habib, N.; Hsu, P.D.; Wu, X.; Jiang, W.; Marraffini, L.A.; et al. Multiplex genome engineering using CRISPR/Cas systems. Science 2013, 339, 819-823. [CrossRef] [PubMed]

Publisher's Note: MDPI stays neutral with regard to jurisdictional claims in published maps and institutional affiliations. 